\title{
The fts $Z$ Gene of Mycobacterium smegmatis is expressed Through Multiple Transcripts
}

\author{
Sougata Roy ${ }^{1,2}$, Deepak Anand ${ }^{1}$, Srinivasan Vijay ${ }^{1}$, Prabuddha Gupta ${ }^{1,3}$ and Parthasarathi Ajitkumar ${ }^{1, *}$ \\ ${ }^{I}$ Department of Microbiology and Cell Biology, Indian Institute of Science, Bangalore-560012, India \\ ${ }^{2}$ Cardiovascular Research Institute, University of California San Francisco, San Francisco, CA 94158, USA \\ ${ }^{3}$ RCE Mechanobiology, National University of Singapore, Singapore
}

\begin{abstract}
The principal essential bacterial cell division gene $f t s Z$ is differentially expressed through multiple transcripts in diverse genera of bacteria in order to meet cell division requirements in compliance with the physiological niche of the organism under different environmental conditions. We initiated transcriptional analyses of fts $Z$ gene of the fast growing saprophytic mycobacterium, Mycobacterium smegmatis, as the first step towards understanding the requirements for FtsZ for cell division under different growth phases and stress conditions. Primer extension analyses identified four transcripts, T1, T2, T3, and T4. Transcriptional fusion studies using $g f p$ showed that the respective putative promoter regions, $\mathrm{P} 1, \mathrm{P} 2, \mathrm{P} 3$, and $\mathrm{P} 4$, possessed promoter activity. $\mathrm{T} 1, \mathrm{~T} 2$, and $\mathrm{T} 3$ were found to originate from the intergenic region between $f t s Z$ and the upstream gene, fts $Q$. T4 was initiated from the $3^{\prime}$ portion of the open reading frame of $f t s Q$. RT-PCR analyses indicated co-transcription of $f t s Q$ and $f t s Z$. The four transcripts were present in the cells at all growth phases and at different levels in the cells exposed to a variety of stress conditions in vitro. $\mathrm{T} 2$ and $\mathrm{T} 3$ were absent under hypoxia and nutrient-depleted stationary phase conditions, while the levels of $\mathrm{T} 1$ and $\mathrm{T} 4$ remained unaffected. These studies showed that fts $Z$ gene expression through multiple transcripts and differential expression of the transcripts at different growth phases and under stress conditions are conserved in M. smegmatis, like in other Actinomycetes.
\end{abstract}

Keywords: Mycobacterium smegmatis, ftsZ, transcripts, promoter, primer extension, hypoxia.

\section{INTRODUCTION}

Eubacterial vegetative cell division by septation is initiated by the cytoskeletal cytokinetic essential protein FtsZ through the formation of polymeric ring structure at the leading edge of the invaginating septum [1, reviewed in 2]. Maintenance of a critical level of FtsZ is obligatory for proper cytokinesis as less or excess of FtsZ results, respectively, in filamentation due to lack of septation or mini cell formation due to septation at the poles of the cells undergoing division [3]. Expression of $f t s Z$ gene has been found to be through co-ordinated differential expression from multiple overlapping transcripts from multiple promoters and/or co-transcription with cell division genes located upstream of fts $Z$ in diverse bacterial systems, Bacillus subtilis [4], Escherichia coli [5-7], Neisseria gonorrhoeae [8], Corynebacterium glutamicum [9, 10], Shewanella violacea [11], Bartonella bacilliformis and Bartonella henselae [12], and Mycobacterium tuberculosis [13]. Although the function of FtsZ is conserved in bacterial systems, expression of $f t s Z$ gene through multiple transcripts has been found to differ markedly among diverse genera of bacteria, in response to different growth phases and various environmental stress conditions, in E. coli [14], N. gonorrhoeae [15], B. subtilis

*Address correspondence to this author at the Department of Microbiology and Cell Biology, Indian Institute of Science, Bangalore-560012, India; Tel: 91-80-2293-2344; Fax: 91-80-2360-2697;

E-mail: ajit@mcbl.iisc.ernet.in
[16], Streptomyces species [17, 18], C. glutamicum [19], Caulobacter crescentus [20], Anabaena sp. strain PCC 7120 [21], and Prochlorococcus sp. strain PCC 9511 [22].

Mycobacterium smegmatis is a saprophytic fast-growing species of mycobacterium, which was originally isolated from human smegma, the natural lubricant produced underneath the foreskin of penis [23]. Although it is not a human pathogen unlike $M$. tuberculosis, being a fast-growing saprophytic species, it is an attractive mycobacterial system to study regulation of expression of cell division genes, such as $f t s Z$, in comparison to those in slow-growing mycobacterial pathogens. In this regard, we had earlier studied fts $Z$ transcription in the slow-growing pathogen, M. tuberculosis $[13,24]$. In the present study, the status of transcription of fts $Z$ of the fast-growing saprophytic $M$. smegmatis (MsftsZ) was determined. Multiple transcripts of MsftsZ were identified, putative promoters of which were mapped, confirmed their promoter activity, detected co-transcription of $M s f t s Z$ with its immediate upstream gene, and examined the profile of $M s f t s Z$ transcripts under different growth phase and stress conditions, which are likely to be experienced by M. smegmatis in its natural environment.

\section{MATERIALS AND METHODS}

\section{Bacterial Strains, Media, and Culture}

M. smegmatis $\mathrm{mc}^{2} 155$ cells [25] were grown in Middlebrook 7H9 (Difco) liquid medium supplemented with $0.2 \%$ 
glycerol, $0.05 \%$ Tween 80 and 10\% Albumin-DextroseCatalase (ADC) enrichment or in Middlebrook 7H10 agar (Difco) medium supplemented with $10 \%$ Oleic acidAlbumin-Dextrose-Catalase (OADC) enrichment. The transformants of $M$. smegmatis cells carrying promoter constructs were grown in the above mentioned liquid or solid media, as the case may be, containing hygromycin at a concentration of $50 \mu \mathrm{g} \mathrm{ml}^{-1}$. E. coli JM109 cells were grown in LuriaBertani (LB) medium in liquid or on LB-solid agar, containing $150 \mu \mathrm{g} \mathrm{ml}^{-1}$ of hygromycin, when required.

\section{Culturing of Cells Under Stress Conditions}

An exponentially growing $M$. smegmatis $\mathrm{mc}^{2} 155$ culture at an $\mathrm{OD}_{600 \mathrm{~nm}}$ of 0.5 was subdivided into a series of $20 \mathrm{ml}$ of cultures, the cells were harvested, resuspended in $10 \mathrm{ml}$ of appropriate stress medium and exposed to stress condition for $2 \mathrm{hrs}$ at $37^{\circ} \mathrm{C}$ in a bacteriological shaker (except heat shock culture, which was kept in non-shaking condition), as described [26]. The stress conditions, $10 \mathrm{mM} \mathrm{H}_{2} \mathrm{O}_{2}$ (oxidative stress), $\mathrm{pH} 5$ (acid stress; $1 \mathrm{M} \mathrm{HCl}$ diluted to get $\mathrm{pH} 5$ ), $0.05 \%$ SDS (detergent stress), and $50^{\circ} \mathrm{C}$ (heat shock), were employed as described [26]. Other stress conditions employed were $5 \mathrm{M} \mathrm{NaCl}$ (hyper-osmotic stress) [27] and 0.2 $\mu \mathrm{g} \mathrm{ml}^{-1}$ of mitomycin C (DNA damage) [28]. Subsequent to exposure to the stress conditions, the cells were harvested and processed, as described [26]. For experiments on cells grown under hypoxia [29], M. smegmatis $\mathrm{mc}^{2} 155$ cells were grown in Dubos broth base (Difco), supplemented with ADC, and containing methylene blue, as described [29, 30]. Disappearance of methylene blue colour marked the onset of hypoxic condition, as described [29]. The $12^{\text {th }}$ day hypoxia culture was harvested, washed in Tween-saline buffer $(0.05 \%$ Tween 80 and $0.8 \% \mathrm{NaCl})$. Hypoxia-exposed bacterial cells were found to be synchronised in growth upon release from hypoxic state, indicating successful reproduction of the slow-stirring model of hypoxia [29], as applied for $M$. smegmatis cells [30]. For generating nutrient-depleted stationary phase cultures, cells were grown to an $\mathrm{OD}_{600 \mathrm{~nm}}$ of 2.5 in a bacteriological shaker and then kept in standing condition for an additional 15 days for the gradual depletion of nutrients, under micro-aerophilic submerged growth.

\section{Growth Synchronisation of M. smegmatis Culture}

Synchronous culture of $M$. smegmatis $\mathrm{mc}^{2} 155$ cells was obtained using phenethyl alcohol (PEA), as described [31]. In brief, the cells were grown in Middlebrook $7 \mathrm{H} 9$ (Difco) liquid medium, supplemented with $0.2 \%$ glycerol, $0.05 \%$ Tween 80, and 10\% Albumin-Dextrose-Catalase (ADC) enrichment, up to $\mathrm{OD}_{600 \mathrm{~nm}}$ of 0.6. Growth was arrested upon treatment with $0.4 \%$ (final concentration) of PEA for $5 \mathrm{hrs}$. The cells were then washed with 1X PBS (phosphatebuffered saline, $\mathrm{pH}$ 7.0), and released from growth arrest by re-suspending in fresh medium and culturing at $37^{\circ} \mathrm{C}$. Synchronisation was ascertained by plating this culture at every $30 \mathrm{~min}$ for $5 \mathrm{hrs}$ and determining colony forming units (cfu) from the samples at the respective time points.

\section{RNA Isolation, Primer Extension Analysis, and RT-PCR Assays}

RNA isolation from mid-log phase $\left(0.6\right.$ at $\left.\mathrm{OD}_{600 \mathrm{~nm}}\right)$ M. smegmatis $\mathrm{mc}^{2} 155$ cells was carried out using hot acid- phenol method, as described [24] or using Tri-reagent (Sigma) following manufacturer's instructions. Primer extension reactions were carried out on $3 \mu \mathrm{g}$ and $5 \mu \mathrm{g}$ RNA from each sample, using MsZPE1 and MsZPE2 primers (Table 1), as described [13]. Sequencing ladders were generated on the sense strand PCR products of the fts $Z$ upstream region, which was amplified from genomic DNA of $M$. smegmatis using primers, MsQf and MsZPE1 (Table 1). The primer extension gel was exposed to phosphorimager cassette to obtain the profile.

Table 1. Primers used in the Study

\begin{tabular}{|c|c|}
\hline MsZPE1 & $5^{\prime}$ ccaaccaccttgatgaccgcgagg $3^{\prime}$ \\
\hline MsZPE2 & $5^{\prime}$ caaccataggcttagagttatgtcaagtag 3 \\
\hline MsQf & $5^{\prime}$ gcgggatccatgaccgacaccaccgagacgaccgca $3^{\prime}$ \\
\hline $\operatorname{mgfp} 1$ & 5 ' ggcgaattcggtaccatgtcgaagggcgaggagctgttcaccggc 3 , \\
\hline $\operatorname{mgfp} 2$ & $5^{\prime}$ gectctagacttgtacagctcgtccatgecgtgggtga 3 , \\
\hline SigA1 & $5^{\prime}$ gctgctgcaggacctgggecgcgag 3 , \\
\hline SigA2 & $5^{\prime}$ cgecgtagacetggecgatctcgtc 3 \\
\hline MsZ1 & $5^{\prime}$ gcgggatccgatatcatgacececcegcac $3^{\prime}$ \\
\hline MsZ2 & $5^{\prime}$ gcgtctagagaattcgtgccgcatgaagggeggc $3^{\prime}$ \\
\hline MshspXf & $5^{\prime}$ gcggatccatgaccaaacttcctgaacgatcacgag $3^{\prime}$ \\
\hline MshspXr & $5^{\prime}$ ccggaattcgtctagacgggetgacggtctccaccg $3^{\prime}$ \\
\hline MsQf-665 & $5^{\prime}$ geccgcacctgttcgaccgc $3^{\prime}$ \\
\hline P1MsZf & $5^{\prime}$ ctagttctgtttgcgeggaactacttgacataactctaagcctat $3^{\prime}$ \\
\hline P1MsZr & $5^{\prime}$ gatcataggcttagagttatgtcaagtagttccgcgcaaacagaa $3^{\prime}$ \\
\hline P2MsZf & $5^{\prime}$ ctaggccacgatcagccgcgtcegeccectaccgttctgtttg $3^{\prime}$ \\
\hline $\mathrm{P} 2 \mathrm{MsZr}$ & 5' gatccaaacagaacggtagggggeggacgcggctgatcgtggc $3^{\prime}$ \\
\hline P3MsZf & $5^{\prime}$ getctagagcccetacggcaagggtttg $3^{\prime}$ \\
\hline P3MsZr & $5^{\prime}$ cgggatccgtggcaggegegceg $3^{\prime}$ \\
\hline P4MsZr & $5^{\prime}$ cgggatcctttgaccgtcggcaggtccgggctc $3^{\prime}$ \\
\hline
\end{tabular}

Restriction enzyme sites are underlined.

For the estimation of relative activity of the individually cloned promoters, semi-quantitative RT-PCR was performed for mycgfp $2+$ in $M$. smegmatis transformants carrying independent promoter-mycgfp $2+$ constructs and for $\operatorname{sig} A$ gene (normalisation control), as described [24]. For RTPCR, amplifications were carried out at 23 cycles (linear range) for $m y c g f p 2+$ and for $\operatorname{sig} A$ from transcriptional fusion transformants, using the combinations of primers, mgfp 1 and mgfp2 and SigA1 and SigA2 (Table 1), respectively. Total amount of $f t s Z$ mRNA and $h s p X$ mRNA were detected by RT-PCR method using specific primer sets (Table 1), MsZ1 and MsZ2 for MsftsZ and MshspXf and MshspXr for $M \operatorname{sh} p X$, respectively. The linear range for RT-PCR amplification was 30 cycles at hypoxia and stationary phase for $f t s Z$ and $h s p X$. Total RNA was used to normalise the amplification. Densitometric quantitations of the cDNA bands for the 
$m y c g f p 2+$ and $\operatorname{sig} A$ mRNAs were carried out using ImageJ software (NIH, USA), from atleast three independent experiments.

For $M s f t s Q-M s f t s Z$ co-transcription analysis, five $\mu \mathrm{g}$ of DNA-free total RNA from $M$. smegmatis cells, which were grown to 0.6 at $\mathrm{OD}_{600 \mathrm{~nm}}$, and 20 pmoles of MsZPE1 primer were added and the volume was made up to $12.5 \mu \mathrm{l}$ with DEPC-treated water. Denaturation of RNA was performed at $65^{\circ} \mathrm{C}$ and snap-cooled on ice for $5 \mathrm{~min}$. Two $\mu 1$ of $10 \mathrm{mM}$ dNTP mix, $4 \mu 1$ of $5 x$ reaction buffer (Fermentas), and 20 units of Ribolock RNase inhibitor (Fermentas) were added. The primer was annealed at $37^{\circ} \mathrm{C}$ for $5 \mathrm{~min}$. RevertAid ${ }^{\mathrm{TM}}$ Premium Reverse Transcriptase (200 U, Fermentas) was added and extension was allowed for $1 \mathrm{hr}$ at $42^{\circ} \mathrm{C}$. Inactivation of Reverse Transcriptase enzyme was carried out at $70^{\circ} \mathrm{C}$ for $10 \mathrm{~min}$. The cDNA synthesised from MsZPE1 was used for the RT-PCR using MsZPE1 in combination with MsQf and MsQf-665 (Table 1) independently to give products of sizes $1292 \mathrm{bp}$ and $628 \mathrm{bp}$, respectively. PCR was performed using Taq DNA polymerase in $25 \mu 1$ reaction volume, where $2 \mu \mathrm{l}$ of the cDNA reaction mixture was used. Total RNA was used as a negative control for no DNA contamination in RT-PCR reaction.

\section{Construction of $M s f t s Z$ Promoter Fusions}

The constructs used or generated in this study are listed in Table 2. The vector pMN406 contains mycgfp $2+$ gene [32], which possesses the same fluorescence enhancing mutations as $g f p+[33]$ and adapted to the mycobacterial codon usage. The imyc promoter of this vector was deleted to generate pMN406- $\Delta \mathrm{P}_{\text {imyc }}$ [24]. Putative promoters, $\mathrm{P} 1$ and $\mathrm{P} 2$, were independently cloned at the BamHI-XbaI sites of pMN406, in place of imyc promoter, after annealing two sets of complementary oligonucleotides, P1MsZf and P1MsZr (for $\mathrm{P} 1$ ), and $\mathrm{P} 2 \mathrm{MsZf}$ and $\mathrm{P} 2 \mathrm{MsZr}$ (for $\mathrm{P} 2$ ), respectively (Table 1). The two respective clones were designated, $\mathrm{pMN} 406-\Delta \mathrm{P}_{\text {imyc }}-\mathrm{P} 1$ and $\mathrm{pMN} 406-\Delta \mathrm{P}_{\text {imyc }}-\mathrm{P} 2$. The putative $116 \mathrm{bp}$ P3 promoter was PCR amplified using primers P3MsZf and P3MsZr, and after sequence verification, cloned at the BamHI-XbaI sites of pMN406, in place of imyc promoter, to generate $\mathrm{pMN} 406-\Delta \mathrm{P}_{\text {imyc }} \mathrm{P} 3$. For cloning $\mathrm{P} 4$, an 879 bp region containing the promoter was PCR amplified using primers, MsQf and P4MsZr (Table 1). The PCR product was cloned in $\mathrm{pBS}(\mathrm{KS})$, sequence-verified, digested with BamHI and SmaI, and the resulting 253 bp region was cloned at the BamHI-SspI sites of pMN406, in place of imyc promoter, to generate $\mathrm{pMN} 406-\Delta \mathrm{P}_{\text {imyc }}-\mathrm{P} 4$.

\section{Flow Cytometry Analyses}

Qualitative detection of promoter activity in M. smegmatis transformants at exponential phase of growth (0.6 at $\mathrm{OD}_{600 \mathrm{~nm}}$ ) was achieved using flow cytometry analyses of MYCGFP2+ protein expressed in the M. smegmatis $\mathrm{mc}^{2} 155$ transformants carrying different $M s f t s Z$ promoter-mycgfp $2+$ fusion constructs, as described [24]. In brief, the cells were harvested at different stages of growth and washed once with phosphate-buffered saline (PBS), and resuspended in $1 \mathrm{ml}$ of PBS. Flow cytometry analysis was performed using Becton Dickinson FACScan machine. Dot plots were analysed using WinMDI software, version 2.8.

\section{RESULTS AND DISCUSSION}

\section{Identification of Four MsftsZ Primer Extension Products}

Primer extension analysis on total RNA from mid-log phase $\left(0.6\right.$ at $\left.\mathrm{OD}_{600 \mathrm{~nm}}\right)$ M. smegmatis $\mathrm{mc}^{2} 155$ cells using MsZPE1 primer (Fig. 1 A; Table 1), 3' end of which anneals at $19 \mathrm{nt}$ downstream of 'A' of the ATG of ftsZ, identified four primer extension products, probably corresponding to four putative transcripts, which were designated, T1, T2, T3, and T4 (Fig. 1 B). The presence of T2, T3, and T4 was further confirmed by extension of another primer MsZPE2 (Fig. 1 C; Table 1), 3' end of which anneals at 92 nt upstream of 'A' of ATG of fts $Z$, within the $f t s Q$ - $f t s Z$ intergenic region (Fig. 1 A). The control experiments using a mixture of $E$. coli tRNA and single-stranded sense-strand DNA did not show any corresponding bands (Fig. 1 B, lane 2), indicating that the primer extension reactions did not involve either non-specific extension or secondary structure-related fall off of the enzyme. T1 starts at A-1060, which is $68 \mathrm{nt}$ upstream of the ' $A$ ' of the ATG of ftsZ (Fig. 2). The corresponding putative promoter $\mathrm{P} 1$ has TAACTC as the -10 sequence, which is located $7 \mathrm{nt}$ upstream of the start site of the transcript, and TTGCGC as the -35 sequence, with a 14 nt gap between the putative -10 and -35 sequences (Fig. 2; Table 3 ). In $M$. smegmatis, the consensus sequences for the -10 and 35 regions for the $A$ group promoter are $T_{94} A_{84} T_{63} a_{42} a_{42} T_{78}$ and $\mathrm{T}_{73} \mathrm{~T}_{58} \mathrm{G}_{68} \mathrm{a}_{26} \mathrm{C}_{57} \mathrm{a}_{36}$, respectively, where the capital letters indicate more than $50 \%$ conservation and the lower case letters indicate conservation between $25 \%$ and $50 \%$, and the subscript number for each nucleotide indicates percent conservation of the nucleotide [34]. Thus, the -10 and -35 sequences of $\mathrm{P} 1$ possess partial consensus to an A group promoter. The $14 \mathrm{bp}$ distance between -10 and -35 sequences seems to be a deviation from the conventional distance of

Table 2. Plasmid Constructs used in the Study

\begin{tabular}{|c|c|c|}
\hline pMN406 & Plasmid containing $m y c g f p 2+$ under the control of $\mathrm{P}_{\text {imyc }}$ promoter, $\mathrm{Hyg}^{\mathrm{r}}$ & {$[32,33]$} \\
\hline $\mathrm{pMN} 406-\Delta \mathrm{P}_{i m y c}$ & pMN406 without promoter $\mathrm{P}_{\text {imyc }}$ & {$[13]$} \\
\hline $\mathrm{pMN} 406-\Delta \mathrm{P}_{i m y c}-\mathrm{P} 1$ & pMN406 containing 41 bp P1 region, in place of Pimyc at BamHI and XbaI sites & This study \\
\hline $\mathrm{pMN} 406-\Delta \mathrm{P}_{\text {imyc }}-\mathrm{P} 2$ & pMN406 containing 39 bp $\mathrm{P} 2$ region, in place of Pimyc at BamHI and XbaI sites & This study \\
\hline $\mathrm{pMN} 406-\Delta \mathrm{P}_{i m y c}-\mathrm{P} 3$ & pMN406 containing 116 bp P3 region, in place of Pimyc at BamHI and XbaI sites & This study \\
\hline $\mathrm{pMN} 406-\Delta \mathrm{P}_{i m y c}-\mathrm{P} 4$ & pMN406 containing 253 bp P4 region, in place of Pimyc at BamHI and SspI sites & This study \\
\hline
\end{tabular}




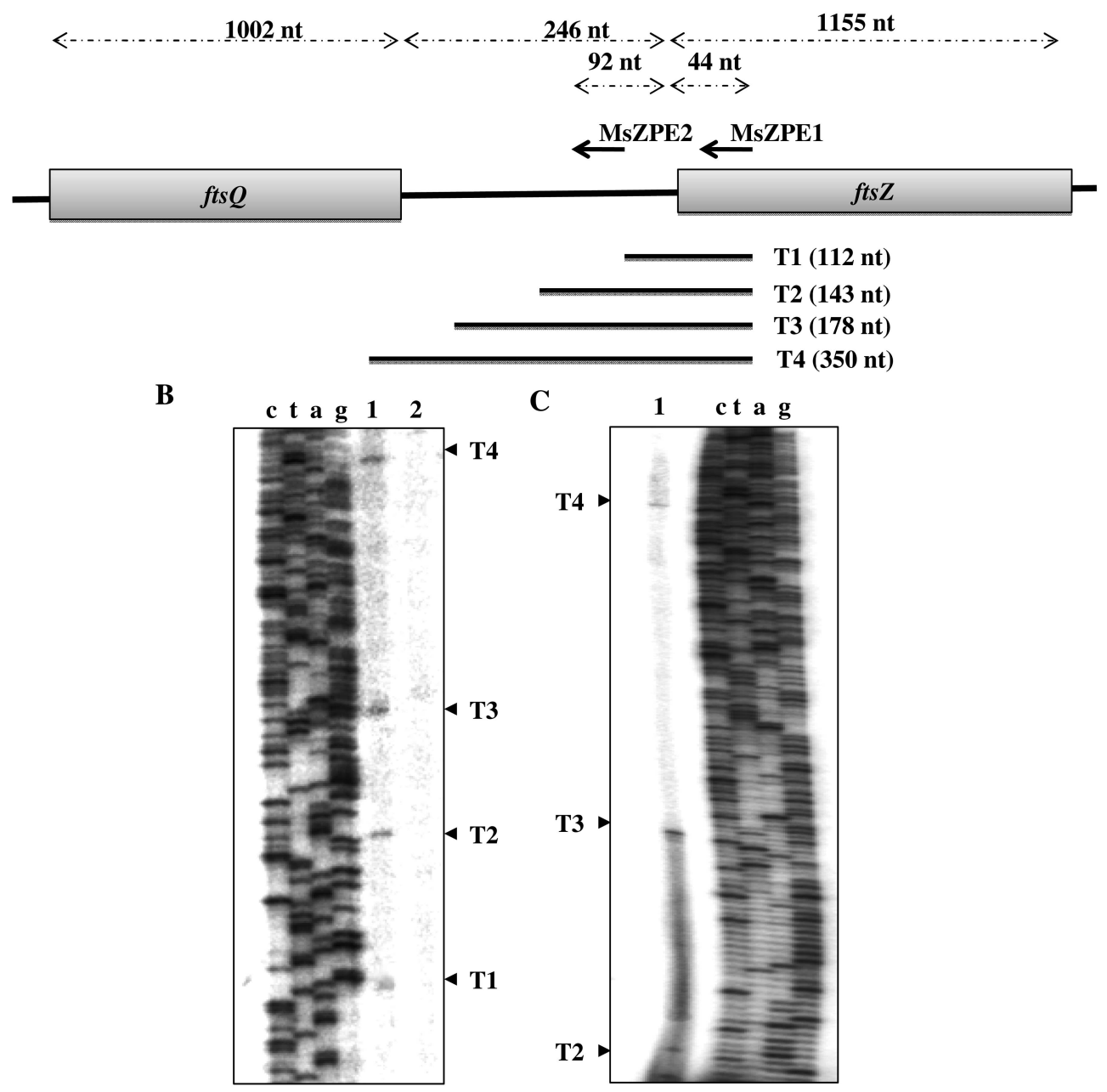

Fig. (1). Primer extension analyses for $f t s Z$ gene of $M$. smegmatis. (A) Schematic representation of the organisation of $f t s Z$ and $f t s Q$ genes of M. smegmaits. MsZPE1 and MsZPE2 primers and positions of their annealing are shown in terms of number of nucleotide (nt). The length of the primer extension products from MsZPE1 primer extension as detected in B and C are shown. (B) and (C) Representative primer extension profiles resolved in Urea-PAGE (6\%). Primer extension using MsZPE1 (B) and MsZPE2 (C) primers on RNA: from, M. smegmatis cells (lane 1) and on E. coli tRNA mixed with single-stranded sense strand of the same region of M. smegmatis (negative control) (lane 2).

16-19 bp found in A group promoters in mycobacteria [34]. Nevertheless, there are several examples of mycobacterial promoters, where -10 and -35 sequences are separated by less than $16 \mathrm{bp}$. Two such examples are the rap promoter of the mycobacterial plasmid, pAL5000 [35], and the gidB promoter of M. smegmatis [36], where in both the cases, the -10 and -35 sequences are separated by a 14 bp stretch.

$\mathrm{T} 2$ originates at G-1028, which is $99 \mathrm{nt}$ upstream of the ATG of fts $Z$ and within the -35 box of P1 (Fig. 2). The -10 sequence TACCGT, which is $7 \mathrm{nt}$ upstream of the mapped +1 site, possesses partial consensus to the -10 sequence, $\mathrm{T}_{85} \mathrm{~A}_{85} \mathrm{NA}_{57} \mathrm{C}_{42} \mathrm{~T}_{71}$, of $\mathrm{B}$ group promoters in mycobacteria [34]. The putative -35 box, CGATCA, is $17 \mathrm{nt}$ upstream of the -10 sequence, TACCGT, and is not conserved (Table 3 ), as observed for B group of mycobacterial promoters [34]. This makes $\mathrm{P} 2$ to be classified as a B group promoter. It has been demonstrated that the -10 regions of mycobacterial promoters are similar to those of E. coli promoters, in contrast to their -35 regions that can tolerate a greater variety of sequences, presumably owing to the presence of multiple sigma factors with different or overlapping specificities for 35 regions [37]. Interestingly, there is the CTGCCA sequence, which is separated from the -10 sequence by $21 \mathrm{bp}$ and possessing partial consensus to the -35 sequence $\left(\mathrm{T}_{73} \mathrm{~T}_{58} \mathrm{G}_{68} \mathrm{a}_{26} \mathrm{C}_{57} \mathrm{a}_{36}\right)$ of A group promoter [34]. Further, the 10 sequence, TACCGT, also shows partial consensus to the 10 sequence, $\mathrm{T}_{94} \mathrm{~A}_{84} \mathrm{~T}_{63} \mathrm{a}_{42} \mathrm{a}_{42} \mathrm{~T}_{78}$, of $\mathrm{A}$ group promoter. In view of these possibilities, pending elucidation of activity, P2 may be grouped as an A group promoter as well. Further, at 5 nt upstream of the T2 start site, P2 region contains a sequence possessing consensus to the -10 sequence, CCGTTC, of SigH [G/C GTT C/A/G, 38, 39] or SigE [G/C GTT C/A/G, 39, 40] also, but without a corresponding -35 consensus sequence. However, we have not carried out detailed mutational studies to determine the exact sequence of the promoter.

T3 starts at A-994, which is 134 nt upstream of the start codon, ATG, of ftsZ (Fig. 2). The putative -10 box ( $8 \mathrm{nt}$ upstream of +1 site), TCGGCG, and the -35 sequence, CGCAGA, are at a distance of $17 \mathrm{nt}$ gap between them. The -10 and -35 sequences do not show consensus to any specific sequence and no other sequences could be detected within the accepted distances of expected -10 and -35 sequences from the transcription start site. Therefore, the putative promoter, which drives the expression of $\mathrm{T} 3$, pending elucidation of activity, was designated as P3 with the putative -10 


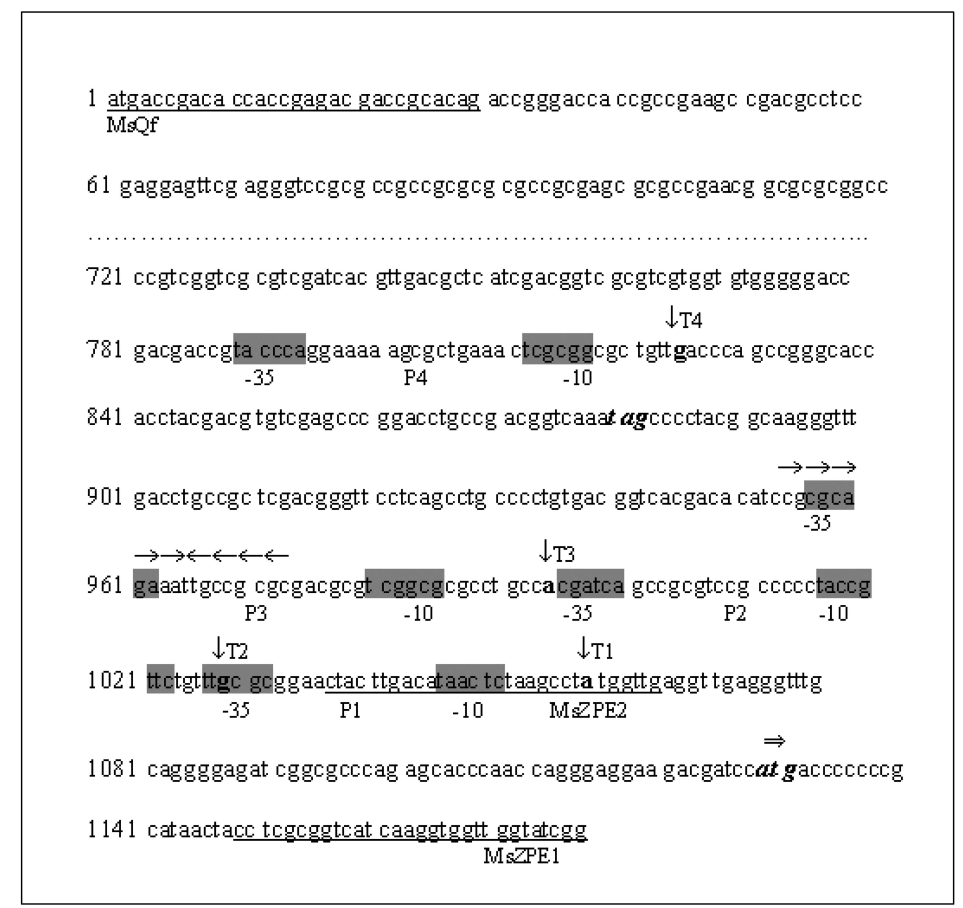

Fig. (2). Promoter map and sequences. The exact location and sequence of the four promoter regions in the $f t s Q$ ORF and $f t s Q-f t s Z$ intergenic region are indicated. Underlined sequences indicate positions of primers MsZPE1, MsZPE2 and MsQf. Shaded box indicates -10 and 35 sequences. Nucleotides in bold font with $\downarrow$ on top indicate the +1 site. Convergent arrows indicate inverted repeats detected by EMBOSS (The European Molecular Biology Open Software Suite) PALINDROME program. TAG stop codon of $f t s Q$ shown in bold italics and ATG of $f t s Z$ was shown with bold italics with arrows on top.

Table 3. Promoter Sequences and Consensus of Mtfts $Z$ Gene

\begin{tabular}{|c|c|c|c|c|}
\hline Promoter & $\mathbf{- 3 5}$ Sequence & $\mathbf{- 1 0}$ Sequence & Nt gap between $\mathbf{- 1 0}$ and $\mathbf{- 3 5}$ seq Consensus to & Promoter[Reference] \\
\hline \hline P1 & TTGCGC & TAACTC & 14 & A group [34] \\
\hline P2 & CGATCA & TACCGT & 17 & B group [34] \\
\hline P3 & CGCAGA & TCGGCG & 17 & C group [34] \\
\hline P4 & TACCCA & TCGCGG & 17 & C group [34] \\
\hline
\end{tabular}

and -35 sequences. According to the $\mathrm{A}, \mathrm{B}, \mathrm{C}$, and $\mathrm{D}$ grouping of promoters, the -10 and -35 sequences of $C$ group promoters do not possess any consensus, but do show promoter activity [34]. Therefore, $\mathrm{P} 3$ was classified as a $\mathrm{C}$ group promoter. Analysis for the presence of repeat sequences using PALINDROME software identified an imperfect inverted repeat only in the P3 region (Fig. 2, indicated by opposing arrows), indicating that the promoter may be subject to regulation. T4 originates at G-825, which is $56 \mathrm{nt}$ upstream of the ' $G$ ' of the stop codon, TAG, of fts $Q$ and 303 nt upstream of the ATG of fts $Z$ (Fig. 2). The putative -10 sequence, TCGCGG ( $7 \mathrm{nt}$ upstream of +1 ), and the -35 sequence, TACCCA, are also spaced by 17 nt gap (Fig. 2; Table 3). The -10 and -35 sequences of $\mathrm{T} 4$ also do not possess any consensus sequence. Therefore, the putative P4 promoter, which has been predicted to transcribe T4, was classified as a $\mathrm{C}$ group promoter [34], pending elucidation of activity.

\section{T1, T2, T3, and T4 are True Transcripts}

In order to verify whether $\mathrm{T} 1, \mathrm{~T} 2, \mathrm{~T} 3$, and $\mathrm{T} 4$ are true transcripts originating from authentic promoters or whether they are RNA processed products, the regions encompassing -10 and -35 sequences, and +1 start sites, of the putative promoter regions, P1, P2, P3, and P4 (Figs. 2, 3 A), were individually cloned in pMN406- $\Delta \mathrm{P}_{\text {imyc }}$ (containing mycgfp $2+$ reporter gene, but without Pimyc promoter; 13, 24) upstream of $m y c g f p 2+$ reporter gene. Flow cytometry analyses for MYCGFP2+ expression in the independent M. smegmatis transformants revealed that P1, P2, P3, and P4 drove expression of $m y c g f p 2+$ (Fig. 3 B). Noticeably, expression from $\mathrm{pMN} 406-\Delta \mathrm{P}_{\text {imyc }}-\mathrm{P} 1, \mathrm{pMN} 406-\Delta \mathrm{P}_{\text {imyc }}-\mathrm{P} 2$ and $\mathrm{pMN} 406-\Delta \mathrm{P}_{\text {imyc }}{ }^{-}$ $\mathrm{P} 4$ were comparably equivalent at $60 \%-70 \%$ higher level of expression, in comparison to the vector control cells (containing pMN406- $\Delta \mathrm{P}_{\text {imyc }}$ ) at the exponential phase of growth. On the contrary, expression from pMN406- $\Delta \mathrm{P}_{\text {imyc }}-\mathrm{P} 3$ was significantly low (19\%) (Fig. 3 B). MYCGFP2+ expression confirmed that P1, P2, P3, and P4 indeed possessed promoter activity. These observations confirmed that the putative transcripts $\mathrm{T} 1, \mathrm{~T} 2, \mathrm{~T} 3$, and $\mathrm{T} 4$ were authentic transcripts that originated from the authentic promoter regions, P1, P2, P3, and $\mathrm{P} 4$, which were predicted based on $5^{\prime}$ end mapping of the transcripts. It may be recalled here that P2 promoter, pending elucidation of activity, could earlier be classified as 


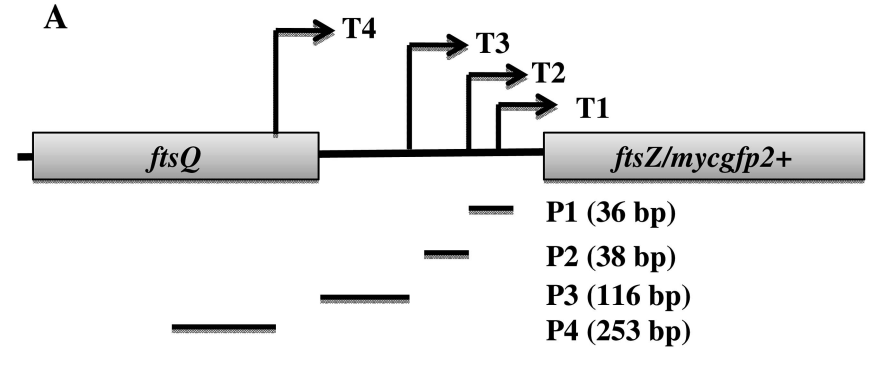

B

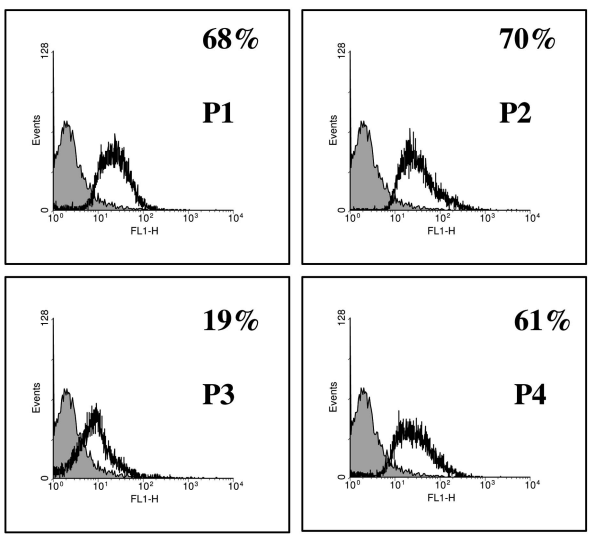

C

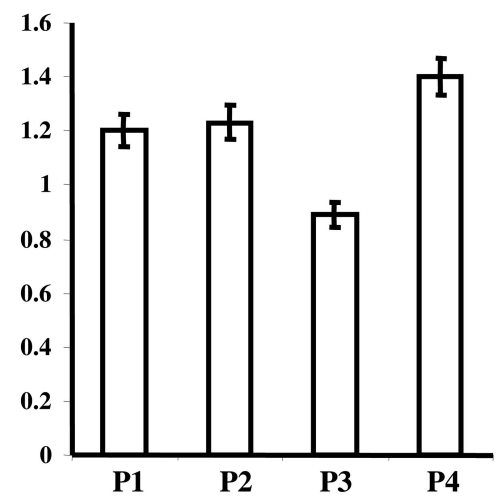

Fig. (3). Promoter activity from cloned $M s f t s Z$ promoter regions. (A) The topographical placement of transcription start point of T1-T4 (arrows) and positions of the putative mapped promoters cloned upstream to mycgfp $2+$ gene of pMN406- $\Delta \mathrm{P}_{\text {imyc }}$ promoter probe vector. (B) Representative histograms from flow cytometry analyses of $M$. smegmatis transformants (carrying independently cloned P1, P2, P3 and P4 promoter regions (indicated in $\mathbf{A}$ ) in the promoter probe vector pMN406- $\Delta \mathrm{P}_{\text {imyc }}$ ) for the MYCGFP2+ activity of the promoters. Blank peaks represent transformants containing mycgfp $2+$ driving promoter regions (P1, P2, P3 and P4) and grey peaks represent the transformants containing pMN406- $\Delta \mathrm{P}_{\text {imyc }}$ vector without promoter insert (negative control). The value for each histogram represent average \% of cells out of three independent experiments that are showing higher fluorescence activity compared to the negative control cells (grey). (C) The graph represents the average relative levels of expression from each cloned promoter region in M. smegmatis cells that were detected using semiquantitative RT-PCR for $m y c g f p 2+$. The values of the $m y c g f p 2+$ amplifications were normalised with respect to sigA amplification values. The graph represents values of experiments from a minimum of three independent samples at exponential growth $\left(0.5\right.$ at $\left.\mathrm{OD}_{600 \mathrm{~nm}}\right)$. The standard deviations are plotted for each value.

a B or A group promoter, based on whether the -35 sequence was CGATCA (17 nt away from -10 sequence; B group) or CTGCCA (21 nt away from -10 sequence; A group). However, the oligonucleotide used for cloning the putative P2 promoter (predicted as belonging to B group of promoters) contained the complete -35 sequence of CGATCA of B group promoter, but only the partial 4 nucleotides, GCCA, of the -35 sequence of CTGCCA of the A group promoter. Since the P2 promoter, which was cloned using this oligonucleotide, showed $70 \%$ higher levels of activity, compared to the negative control (Fig. 3 B), the authentic -35 sequence of P2 promoter might be CGATCA, and not CTGCCA, thereby classifying it as a B group promoter (Table $\mathbf{3}$ ).

It may be noted here that GFP being a protein having long half-life, the levels of MYCGFP2+ expression was considered only as a means for the detection of promoter activity and not for the quantitative evaluation of the contribution of activity from the individual promoters. Therefore, in order to measure the relative levels of activity of the individual promoters, the levels of mycgfp $2+$ mRNA produced by the four individually cloned promoter regions were measured. For this purpose, semi-quantitative RT-PCR was carried out on the total RNA isolated from the M. smegmatis transformants, carrying the promoter-reporter gene constructs, at the exponential phase of growth $\left(0.5\right.$ at $\left.\mathrm{OD}_{600 \mathrm{~nm}}\right)$. The levels of expression of mycgfp $2+$ mRNA was detected and normalised with respect to the level of expression of $\operatorname{sig} A$ as described earlier [13, 24]. The levels of expression from P1, P2 and P4 were found to be comparably equivalent (Fig. 3 C). Expression from P3 was found to be lower than that from P1 or P2 (about 1.3-fold lower, P value 0.0058, SD 0.015) and P4 (about 1.6-fold lower, P value 0.0009, SD 0.01) (Fig. 3 C). However, it may be noted here that the actual level of activity of a promoter could be very different in the genomic context in vivo than from the cloned minimal region containing $+1,-10$, and -35 sequences upstream of mycgfp $2+$.

The fts $Z$ gene has been found to get expressed through multiple transcripts in many Gram-positive bacterial genera, B. subtilis [4], C. glutamicum [9, 10], Streptomyces species $[17,18,41]$, and M. tuberculosis [13], and in Gram-negative bacteria, E. coli [5-7, 42], N. gonorrhoeae [8], S. violacea [11], and B. bacilliformis and B. henselae [12]. The organisation of the region spanning $f t s Q$ open reading frameintergenic region- $f t s Z$ open reading frame, is conserved in all mycobacterial species and in lower Actinomycetes species. Similarly, the presence of multiple $f t s Z$ promoters and their 
organisation, which were found conserved in Streptomyces species [17, 18, 41], Corynebacterium [10], and M. tuberculosis [13], was present in M. smegmatis also. Since Streptomyces species, Corynebacterium, and Mycobacteria belong to Actinomycete family, it is possible that the similarity in the organisation of multiple promoters and the pattern of transcription of $f t s Z$ from multiple promoters in these members of Actinomycete family (Streptomyces, Corynebacterium, and Mycobacteria) probably might have originated from a common ancestral pattern.

\section{Co-Transcription of $M s f t s Q$ and $M s f t s Z$}

Presence of transcript originating in the fts $Q$ region and apparent absence of any transcription terminator sequence within the fts $Q$-fts $Z$ intergenic region were indicative of the possibility that fts $Q$ and $f t s Z$ might be getting co-transcribed in $M$. smegmatis. In order to verify such a possibility, cDNA was generated using MsZPE1 primer on total RNA from $M$. smegmatis $\mathrm{mc}^{2} 155$ cells (Table 1; Fig. 4 A). The cDNA was amplified independently using two sets of primer pairs. These were MsQf and MsZPE1 pair and MsQf-665 and MsZPE1 pair (Table 1; Fig. 4 A). The MsQf and MsZPE1 pair would yield 1292 bp product $(1002 \mathrm{bp}+246 \mathrm{bp}+44$ bp), spanning MsftsQ ORF (1002 bp), MsftsQ-Msfts Z intergenic region (246 bp), and $44 \mathrm{bp}$ of the 5' region of $M s f t s Z$
ORF (Fig. 4 A). Similarly, the MsQf-665 and MsZPE1 pair would give $628 \mathrm{bp}$ product (338 bp $+246 \mathrm{bp}+44 \mathrm{bp})$, comprising of 3' region of $M s f t s Q$ (338 bp), Msfts $Q-M s f t s Z$ intergenic region (246 bp), and 5' region of MsftsZ ORF (44 bp) (Fig. $4 \mathrm{~A}$ ). These two primer sets gave the expected size products of $1292 \mathrm{bp}$ and $628 \mathrm{bp}$, respectively from the cDNA (Fig. 4 B, lanes 2 and 4, respectively). The same primer sets were also used for PCR on genomic DNA to yield same products, $1292 \mathrm{bp}$ and $628 \mathrm{bp}$, as positive controls (Fig. 4 B, lanes 1 and 3, respectively). The templateminus negative control sample (RNA alone) did not yield any PCR product (Fig. 4 B, lane 5). These observations revealed that $M s f t s Q$ and $M s f t s Z$ are co-transcribed in $M$. smegmatis $\mathrm{mc}^{2} 155$ cells.

Although the farthest $M s f t s Z$ promoter that has been mapped in this study is $\mathrm{P} 4$, which is in the reading frame of the upstream gene, Msfts $Q$, co-transcription of $M s f t s Q$ and $M s f t$ Z indicates the possibility that the promoter(s) of $M s f t s$ are likely to be involved in controlling the expression of $M s f t s Z$ as well, through co-transcription with $M s f t s Q$. Such instances of co-transcription of $f t s Z$ with upstream gene and controlled by far upstream promoters have been documented in many bacterial genera. For instance, in E. coli, a large proportion of the $f t s Z$ transcription comes through cotranscription from two promoters, $f t s Q 2 p$ and $f t s Q 1 p$, which

A

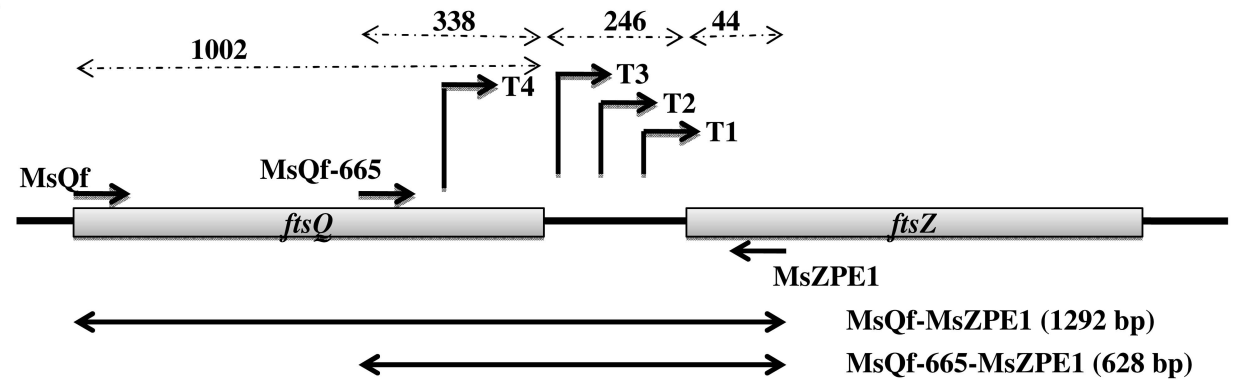

B

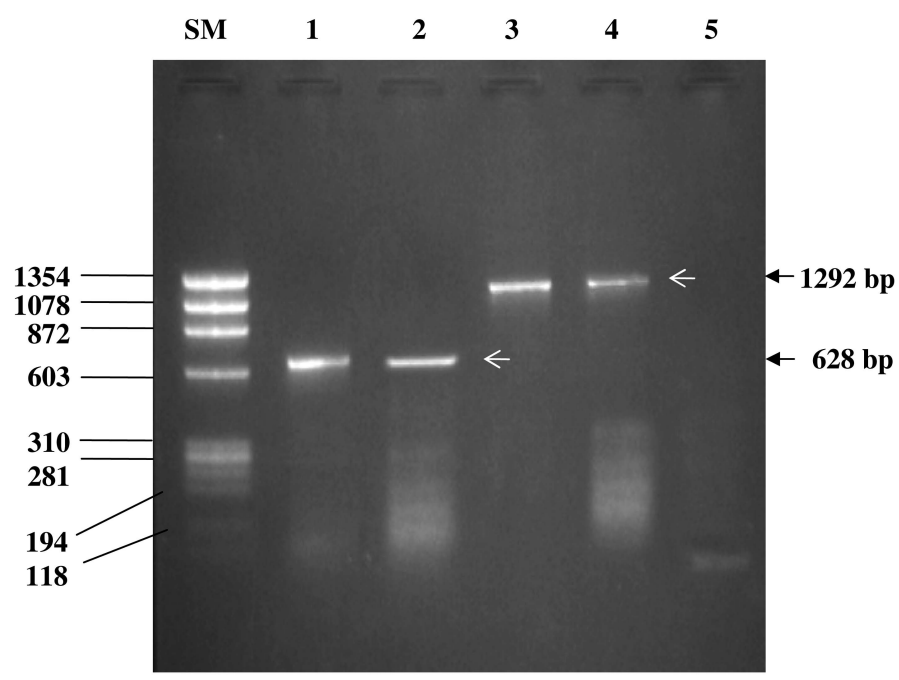

Fig. (4). Co-transcription of $f t s Q$ and $f t s Z$ in $M$. smegmatis (Ms) cells. (A) The schematic diagram indicates the positions of the primers used for cDNA synthesis RT-PCR and the sizes of the PCR products encompassed by the primer pairs. (B) Profile of RT-PCR products. Lanes: SM, Size Marker $\Phi X 174$ DNA/BsuRI (HaeIII); 1, Ms genomic DNA PCR with MsZPE1 and MsQf-665 (628 bp), showing the expected product; 2, MsZPE1 cDNA used for RT-PCR with MsZPE1 and MsQf-665 primers (628 bp), indicating transcriptional input from ftsQ ORF to ftsZ; 3, Ms genomic DNA PCR with MsZPE1 and MsQf (1292 bp), showing the expected product; 4, MsZPE1 cDNA used for RT PCR with MsZPE1 and MsQf (1292 bp), indicating co-transcription of $f t s Q$-fts $Z$ genes; 5, RNA template as negative control. 
are located 5 ' to the second upstream gene, fts $Q[5,6,7,14]$. Similarly, in $N$. gonorrhoeae, one promoter that is 5 ' to the second upstream gene, fts $Q$, drives expression of $f$ ts $Z$ as a co-transcript with fts $Q$ [8]. Low abundance transcription of C. glutamicum fts $Z$ was observed as a bicistronic mRNA from a promoter 5 ' to the upstream $f$ ts $Q$ gene [10]. One of the promoters, from which $B$. subtilis fts $Z$ is transcribed, is located 5' to the upstream gene, fts $A$ [4]. Four transcripts of $B$. bacilliformis fts $Z$ are synthesised as co-transcripts with upstream genes [12]. Thus, the trend of co-transcription of fts $Z$ with the upstream gene under the control of upstream promoters is conserved in the transcription of $M s f t s Z$ also.

\section{MsftsZ Transcripts Under Different Growth Phases}

Various growth phase-specific alterations in the number of $f t s Z$ transcripts have been reported in many bacterial systems. For instance, in E. coli, while all the five fts $Z$ promoters are active during exponential phase of growth, the $f t s Q 1 p$ promoter, which is weakly active during exponential phase, gets strongly induced during stationary phase [43]. Similarly, in B. subtilis, while the promoters, $\mathrm{P} 1$ and $\mathrm{P} 3$, are active during vegetative phase, $\mathrm{P} 2$ gets activated only during sporulation [16]. In the lower Actinomycete, C. glutamicum, all the five promoters of $f t s Z$ are active only during exponential phase and are down-regulated during stationary phase [19]. While the $f t s Z 2 p$ promoter in S. coelicolor is essential for sporulation but not for vegetative growth [18], in S. griseus, the Pveg promoter is active moderately during vegetative growth, but gets switched off within the first $2 \mathrm{hrs}$ of sporulation and, instead, two sporulation-specific transcripts are synthesised up to 5 -fold, shortly before the formation of sporulation septa [41]. For these reasons, and M. smegmatis

A

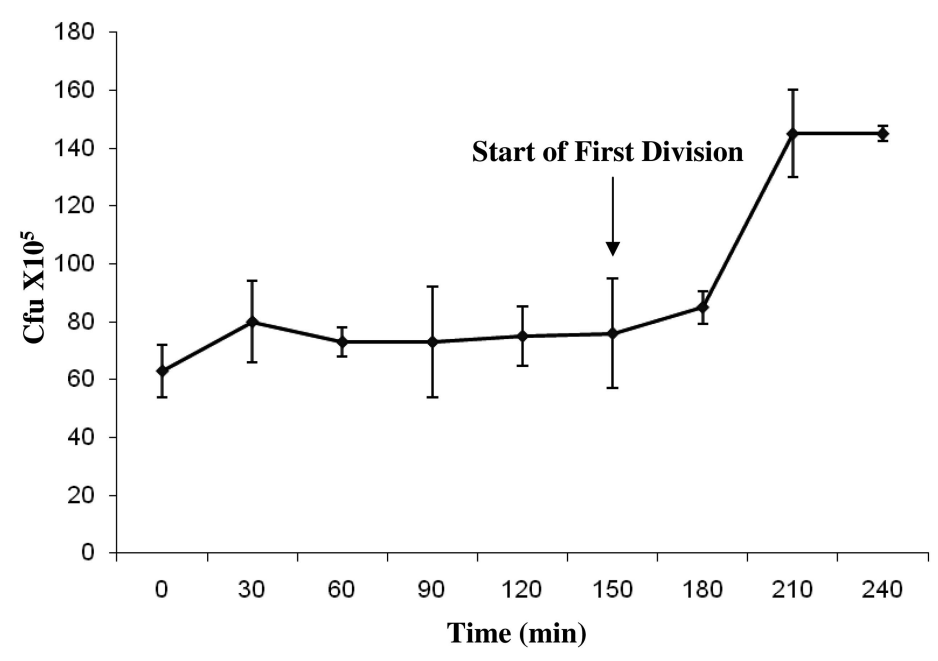

being a member of the Actinomycete family to which Streptomyces and Corynebacterium belong, it was of interest to find out whether all the four transcripts, T1, T2, T3, and T4, and/or whether any new $M s f t s Z$ transcripts were synthesised under different growth phases. In order to study the profile of Msfts $Z$ transcripts under different growth phases, phenethyl alcohol (PEA) was used to synchronise M. smegmatis cells in culture, as described [31]. Release from PEAmediated growth arrest showed synchronous progression of cells through growth and cell division (Fig. 5 A), indicating successful synchronisation using PEA. The cells in the synchronised culture were consistently found to start division by $150 \mathrm{~min}$ post-release and finish division by $210 \mathrm{~min}$, with the 0 time point being the time point at which the cells were released into fresh medium, post-exposure to PEA.

Primer extension was carried out on $3 \mu \mathrm{g}$ of total RNA isolated from the cells harvested at $0 \mathrm{~min}, 150 \mathrm{~min}, 210 \mathrm{~min}$, and $240 \mathrm{~min}$ (a time point that is beyond one division cycle of about $3 \mathrm{hrs}$ for M. smegmatis cells). All the four transcripts, $\mathrm{T} 1, \mathrm{~T} 2, \mathrm{~T} 3$, and $\mathrm{T} 4$, were present in growth-arrested cells as well as at all the phases of growth and division, postrelease from PEA block (Fig. 5 B). However, relative densitometric quantitation of the transcript bands, generated from the same amount of RNA (Fig. 5 B, lower panel), showed that the ratio of $\mathrm{T} 2$ at $0 \mathrm{~min}$ post-release to $\mathrm{T} 2$ of exponential phase $(0.57 \pm 0.03)$ was significantly low (P value, 0.0001 $0.0003)$ in all the repeat experiments $(\mathrm{n}=3)$, as compared to the same at other time points $(0.95 \pm 0.04$ at $\mathrm{t}=240,0.92 \pm$ 0.02 at $\mathrm{t}=210$ and $0.87 \pm 0.02$ at $\mathrm{t}=150)$. The ratio of $\mathrm{T} 2$ at 0 min post-release to $\mathrm{T} 2$ of exponential phase also showed a gradual recovery from $t=0(0.57 \pm 0.03)$ to $t=150 \mathrm{~min}$ $(0.87 \pm 0.02)$, prior to division. The ratio of the levels of $\mathrm{T} 2$

\section{B}

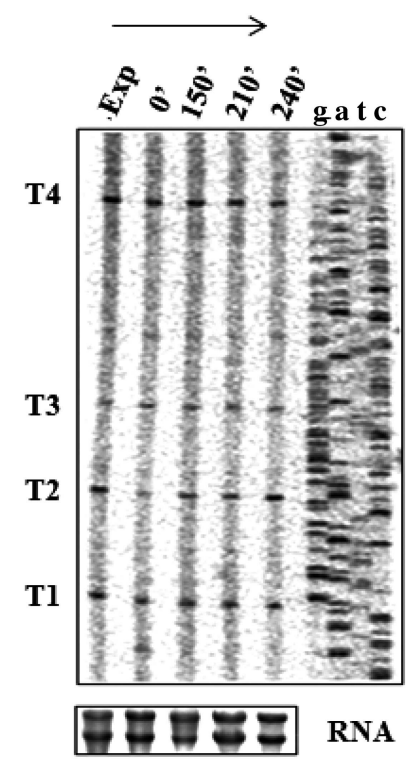

Fig. (5). Synchronous growth of M. smegmatis and profile of T1-T4 transcripts. (A) Synchronous growth curve of $M$. smegmatis culture upon release from PEA treatment. The time points (post-release from PEA), at which the cells were harvested for analysis, are shown on Xaxis. The arrow shows start of synchronous division post-release from PEA (at $150 \mathrm{~min}$ ). (B) Primer extension analysis using primer MsZPE1 from $3 \mu \mathrm{g}$ RNA (lower panel) from each time point (0 min, $150 \mathrm{~min}, 210 \mathrm{~min}$, and $240 \mathrm{~min}$ ) post-release from PEA treatment and consequent growth arrest, compared to the exponential culture (Exp). Profiles of RNA samples used for primer extension are shown in lower panel. 
at $\mathrm{t}=210$ to that of $\mathrm{T} 2$ at exponential phase $(0.92 \pm 0.02)$ or at $\mathrm{t}=240$ to that of $\mathrm{T} 2$ at exponential phase $(0.95 \pm 0.04)$, after division, becomes comparable to the levels of T2 at exponential phase. Such changes were not found for T1, T3, and T4. These observations indicate that even though all the transcripts are synthesised at various phases of synchronous growth, T2 expression is significantly reduced upon growth arrest, which over a period, gradually becomes normal, prior to division and subsequent growth. However, it is not clear whether this reduction is a manifestation of growth arrestspecific change in the transcription from $\mathrm{P} 2$ promoter or a stress response effect on $\mathrm{P} 2$ promoter due to growth arrest by PEA.

\section{Msfts $Z$ Transcripts Under Different Stress Conditions}

Besides growth phase-specific changes in $f t s Z$ expression, it has been reported that altered expression of fts $Z$ can influence cytokinesis, resulting in cell division modulation under stress conditions. For instance, among the three $N$. gonorrhoeae fts $Z$ transcripts, Pz1, Pz2, and Pz3, Pz1 alone was expressed prominently and strongly under anaerobic condition $[8,15]$. Reduction in expression of all the transcripts was observed in the presence of urea, which is one of the stress conditions that exist in the environment of the genitourinary tract [15]. Similarly, in S. coelicolor A3(2), which comes under Actinomycete family to which mycobacteria belong, the transcript from $f t s Z 2 p$ promoter was predominantly expressed during nutrient stress leading to sporulation (vegetative growth inhibition) and inactivation of the promoter was found to affect sporulation septation [18]. The in vitro and in vivo stress conditions, namely heat shock, acid stress, oxidative stress, detergent, osmotic, DNA damage, hypoxia, and nutrient-depleted stationary phase are experienced by the pathogen, M. tuberculosis, in human host [26-29]. M. smegmatis, although a saprophyte, has also been found to mount response to some of these stress conditions in a manner comparable to that mounted by M. tuberculosis $[27,30]$. For these reasons, it was of interest to find out whether all the four transcripts, T1, T2, T3, and T4, and/or whether any new $M s f t s Z$ transcript(s) were synthesised under different stress conditions.

For this purpose, total RNA was isolated from $M$. smegmatis cells exposed individually to heat shock, acid stress, oxidative stress, detergent stress, osmotic stress, and DNA damage stress in vitro, and from cells under hypoxia and nutrient-depleted stationary phase in vivo. Primer extension analyses were carried out with MsZPE1 primer (Fig. 1 A; Table 1) on $3 \mu \mathrm{g}$ of total RNA from each sample. The T1, T2, T3, and T4 transcripts were present, with some changes in their levels, under all the in vitro stress conditions. Besides the identified 4 transcripts, no new transcript(s) could be detected (Fig. 6 A). Relative densitometric quantitation from several gels for each band indicated that the levels of T2 and T3 transcripts varied under different stress conditions. While T1 and T4 transcripts remained unaffected, T3 transcript level was found slightly reduced under most of the stress conditions. T2 level was found to be low under all the conditions and could barely be detected under SDS stress. In order to determine the general relative trend in the stress responsiveness of $\mathrm{P} 2$ promoter with respect to $\mathrm{P} 1$, under heat shock, semi-quantitative RT-PCR was carried out on total RNA for mycgfp $2+$ mRNA from $M$. smegmatis transformants, carrying pMN406- $\Delta \mathrm{P}_{\text {imyc }}-\mathrm{P} 2$ and $\mathrm{pMN} 406-\Delta \mathrm{P}_{\text {imyc }}-\mathrm{P} 1$ promoter constructs. While the ratio of the levels of mRNA
A

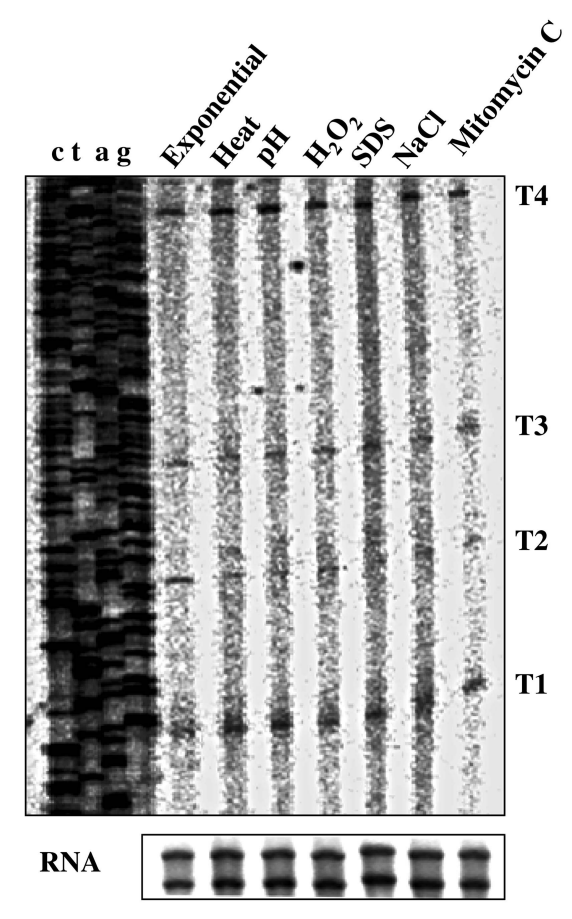

B

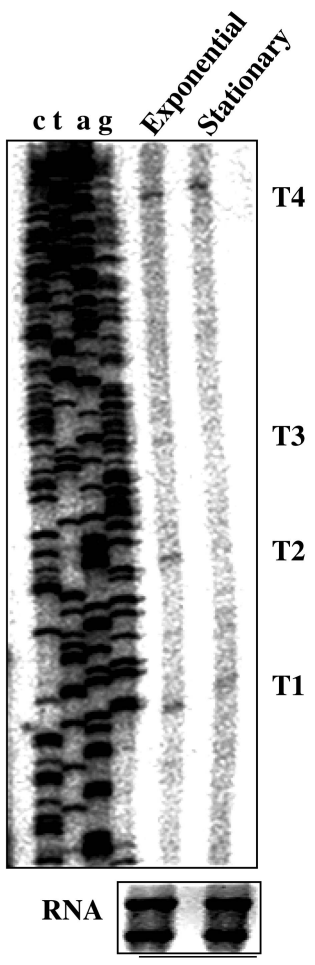

C

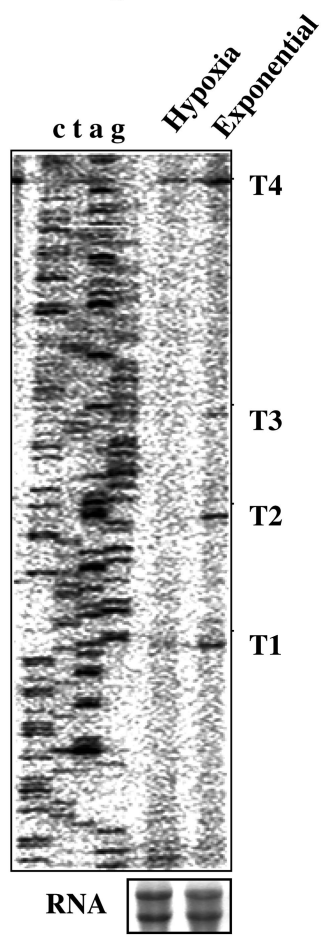

Fig. (6). Primer extension (PE) profile of T1, T2, T3, and T4 transcripts from the cells under various in vitro and in vivo stress conditions. (A) Various in vitro stress conditions. (B) nutrient-depleted stationary phase. (C) hypoxia-induced NRP2 stage. Profile of RNA samples used for the analyses is shown in box below the PE gel. 
of $m y c g f p 2+$ to $\operatorname{sig} A$ remained constant for $\mathrm{P} 1$ transcriptional fusion at exponential phase and under heat-shock condition, activity of P2 (measured by RT-PCR for $m y c g f p 2+$ to $\operatorname{sig} A$ mRNA) was found reduced by 1.6 -fold. This indicated that in vitro stress conditions such as heat shock do affect differential expression of $f t s Z$ transcripts, as revealed in the primer extension assay.

Similarly, under hypoxia and nutrient-depleted stationary phase conditions, only T1 and T4 transcripts, but not T2 and T3 or any new transcript(s), were present in the cells (Fig. 6 $\mathbf{B}, \mathbf{C})$. In order to test whether the differential expression of fts $Z$ by different promoters was really reflected in the differential levels of fts $Z$ mRNA, the levels of $f t s Z$ mRNA (normalised with respect to total RNA) were determined using semi-quantitative RT-PCR on total RNA from the cells under hypoxia and nutrient-depleted stationary phase of growth. About $50 \%$ reduction in the total $\mathrm{fts} Z$ mRNA levels was observed during hypoxia and nutrient-depleted stationary phase of growth, compared to that in exponential culture. The hspX mRNA, which is the molecular marker upregulated under this condition in mycobacteria [44-48], showed 2 -fold increase, confirming that the cells were indeed under hypoxia. These observations indicated that there was reduction in the level of $f t s Z$ expression through the modulation of the expression of $\mathrm{P} 2$ and $\mathrm{P} 3$ promoters in M. smegmatis cells under nutrient-depleted stationary phase and hypoxic conditions of growth.

Thus, taken together, differential expression of $f t s Z$ gene through multiple transcripts and through co-transcription with the immediately upstream gene are conserved in $M$. smegmatis, as in other diverse bacterial genera, especially in other Actinomycetes to which M. smegmatis belong. In addition to the differential expression of transcripts, it is possible that the transcripts are differentially processed and/or translated, thereby modulating FtsZ protein levels and affecting cytokinesis, as critical levels of FtsZ are essential for septation [3]. Nevertheless, as in other bacterial systems, differential expression of $f t s Z$ gene from multiple promoters might facilitate regulation of cell division at different growth phases and in response to various environmental stress conditions, which M. smegmatis might be exposed to.

\section{ACKNOWLEDGEMENTS}

The work was supported by grants from the DBT - Infrastructure Programme Support for Basic Biological Research / Pathogen Biology at Indian Institute of Science and in part from the part-grant from the DBT Centre of Excellence in Tuberculosis. The authors thank Dr. Michael Niederweis for pMN406 vector. Dr. Omana Joy, Flow Cytometry Facility at the Division of Biological Sciences, Indian Institute of Science, is gratefully acknowledged for the technical support in flow cytometry analyses. SR and SV acknowledge senior research fellowships from the Council of Scientific and Industrial Research, Government of India, during the present study.

\section{REFERENCES}

[1] Bi EF, Lutkenhaus J. FtsZ ring structure associated with division in Escherichia coli. Nature 1991; 35: 161-4.

[2] Addinall SG, Holland B. The tubulin ancestor, FtsZ, draughtsman, designer and driving force for bacterial cytokinesis. J Mol Biol 2002; 318: 219-36.
[3] Ward JE Jr, Lutkenhaus J. Overproduction of FtsZ induces minicell formation in E. coli. Cell 1985; 42: 941-9.

[4] Gholamhoseinian A, Shen Z, Wu J-J, Piggot P. Regulation of transcription of the cell division gene ftsA during sporulation of Bacillus subtilis. J Bacteriol 1992; 174: 4647-56.

[5] Flardh K, Palacios P, Vicente M. Cell division genes fts $Q A Z$ in Escherichia coli require distant cis-acting signals upstream of $d d l B$ for full expression. Mol Microbiol 1998; 30: 305-15.

[6] Mengin-Lecreulx D, Ayala J, Bouhss A, van Heijenoort J, Parquet C, Hara H. Contribution of the Pmra promoter to expression of genes in the Escherichia coli mra cluster of cell envelope biosynthesis and cell division genes. J Bacteriol 1998; 180: 4406-12.

[7] de la Fuente A, Palacios P, Vicente M. Transcription of the Escherichia coli $d c w$ cluster: Evidence for distal upstream transcripts being involved in the expression of the downstream fts $Z$ gene. Biochimie 2001; 83: 109-15.

[8] Francis F, Ramirez-Arcos S, Salimnia H, Victor C, Dillon JR. Organisation and transcription of the division cell wall $(d c w)$ cluster in Neisseria gonorrhoeae. Gene 2000; 251: 141-51.

[9] Honrubia MP, Fernandez FJ, Gil JA. Identification, characterisation, and chromosomal organisation of the fts $Z$ gene from Brevibacterium lactofermentum. Mol Gen Genet 1998; 259: 97-104.

[10] Ramos A, Honrubia MP, Vega D, et al. Characterisation and chromosomal organisation of the murD-murC-fts $Q$ region of Corynebacterium glutamicum ATCC 13869. Res Microbiol 2004; 155: 174-84.

[11] Ishii A, Nakasone $\mathrm{K}$, Sato T, et al. Isolation and characterisation of the $d c w$ cluster from the piezophilic deep-sea bacterium Shewanella violacea. J Biochem 2002; 132: 183-8.

[12] Fiskus W, Padmalayam I, Kelly T, Guibao C, Baumstark BR. Identification and characterisation of the DdlB, FtsQ and FtsA genes upstream of FtsZ in Bartonella bacilliformis and Bartonella henselae. DNA Cell Biol 2003; 22: 743-52.

[13] Roy S, Ajitkumar P. Transcriptional analysis of the principal cell division gene, ftsZ, of Mycobacterium tuberculosis. J Bacteriol 2005; 187: 2540-50.

[14] Flardh K, Garrido T, Vicente M. Contribution of individual promoters in the $d d l B-f t s Z$ region to the transcription of the essential cell-division gene ftsZ in Escherichia coli. Mol Microbiol 1997; 24: 927-36.

[15] Ramirez-Arcos S, Salimnia H, Bergevin I, Paradis M, Dillon JA. Expression of Neisseria gonorrhoeae cell division genes ftsZ, ftsE and $\min D$ is influenced by environmental conditions. Res Microbiol 2001; 152: 781-91.

[16] Gonzy-Treboul G, Karmazyn-Campelli C, Stragier P. Developmental regulation of transcription of the Bacillus subtilis ftsAZ operon. J Mol Biol 1992; 224: 967-79.

[17] Dharmatilake AJ, Kendrick KE. Expression of the divisioncontrolling gene fts $Z$ during growth and sporulation of the filamentous bacterium Streptomyces griseus. Gene 1994; 147: 21-8.

[18] Flärdh K, Leibovitz E, Buttner MJ, Chater KF. Generation of a non-sporulating strain of Streptomyces coelicolor A3(2) by the manipulation of a developmentally controlled fts $Z$ promoter. Mol Microbiol 2000; 38: 737-49.

[19] Letek M, Ordonez E, Fiuza M, et al. Characterisation of the promoter region of fts $Z$ from Corynebacterium glutamicum and controlled overexpression of FtsZ. Internat Microbiol 2007; 10: 271-82.

[20] Kelly AJ, Sackett MJ, Din N, Quardokus E, Brun YV. Cell cycle-dependent transcriptional and proteolytic regulation of FtsZ in Caulobacter. Genes Dev 1998; 12: 880-93.

[21] Kuhn I, Peng L, Bedu S, Zhang CC. Developmental regulation of the cell division protein FtsZ in Anabaena sp. strain PCC 7120, a cyanobacterium capable of terminal differentiation. J Bacteriol 2000; 182: 4640-3.

[22] Holtzendorff J, Partensky F, Jacquet S, et al. Diel expression of cell cycle-related genes in synchronised cultures of Prochlorococcus $s p$. strain PCC 9511. J Bacteriol 2001; 183: 915-20.

[23] Alvarez E, Tavel E. Recherches sur le bacille' de Lustgarden. Archives de Physiologie Normale et Pathologique 1885; 6: 303-21. Roy S, Mir MA, Anand SP, Niederweis M, Ajitkumar P. Identification and semi-quantitative analysis of Mycobacterium tuberculosis $\mathrm{H} 37 \mathrm{Rv}$ fts $\mathrm{Z}$ gene-specific promoter activity-containing regions. Res Microbiol 2004; 155: 817-26.

[25] Snapper SB, Melton RE, Mustafa S, Kieser T, Jacobs WR Jr Isolation and characterization of efficient plasmid transformation 
mutants of Mycobacterium smegmatis. Mol Microbiol 1990; 4: 1911-9.

[26] Manganelli R, Dubnau E, Tyagi S, Kramer FR, Smith I. Differential expression of 10 sigma factor genes in Mycobacterium tuberculosis. Mol Microbiol 1999; 31: 715-24.

[27] Smeulders MJ, Keer J, Speight RA, Williams HD. Adaptation of Mycobacterium smegmatis to stationary phase. J Bacteriol 1999; 181: 270-83.

[28] Rand L, Hinds J, Springer B, Sander P, Buxton RS, Davis EO. The majority of inducible DNA repair genes in Mycobacterium tuberculosis are induced independently of RecA. Mol Microbiol 2003; 50: 1031-42.

[29] Wayne LG, Hayes LG. An in vitro model for sequential study of shiftdown of Mycobacterium tuberculosis through two stages of nonreplicating persistence. Infect Immun 1996; 64: 2062-9.

[30] Dick T, Lee BH, Murugasu-Oei B. Oxygen depletion induced dormancy in Mycobacterium smegmatis. FEMS Microbiol Lett 1998; 163: 159-64.

[31] Mizuguchi Y. Synchronisation of Mycobacterium smegmatis culture by phenethyl alcohol and nitrosoguanidine mutagenesis. Igaku To Seibutsugaku 1970; 81: 215-20.

[32] Steinhauer K, Eschenbacher I, Radischat N, Detsch C, Niederweis $\mathrm{M}$, Goroncy-Bermes P. Rapid evaluation of the mycobactericidal efficacy of disinfectants in the quantitative carrier test EN 14563 by using fluorescent Mycobacterium terrae. Appl Environ Microbiol 2010; 76: 546-54.

[33] Scholz O, Thiel A, Hillen W, Niederweis M. Quantitative analysis of gene expression with an improved green fluorescent protein. Eur J Biochem 2000; 267: 1565-70.

[34] Gomez M, Smith I. Determinants of mycobacterial gene expression. In: Hatfull GF, Jacobs WR Jr, Eds. Molecular Genetics of Mycobacteria. Washington, DC, USA: ASM Press 2000; 111-29.

[35] Stolt P, Zhang Q, and Ehlers M. Identification of promoter elements in mycobacteria: mutational analysis of a highly symmetric dual promoter directing the expression of replication genes of the Mycobacterium plasmid pAL5000. Nucl Acids Res 1999; 27: 396-402.

[36] Casart Y, Gamero E, Rivera-Gutierrez S, González-y-Merchand JA, Salazar L. par genes in Mycobacterium bovis and Mycobacterium smegmatis are arranged in an operon transcribed from "SigGC" promoters. BMC Microbiol 2008; 8: 51. doi:10.1186/1471-2180$8-51$.
[37]

Bashyam MD, Kaushal D, Dasgupta SK, Tyagi AK. A study of the mycobacterial transcriptional apparatus: identification of novel features in promoter elements. J Bacteriol 1996; 178: 4847-53.

[38] Raman S, Song T, Puyang X, Bardarov S, Jacobs WR Jr, Husson $\mathrm{RN}$. The alternative sigma factor SigH regulates major components of oxidative and heat stress responses in Mycobacterium tuberculosis. J Bacteriol 2001; 183: 6119-25.

[39] Rodrigue S, Provvedi R, Jacques P-E, Gaudreau L, Manganelli R. The $\sigma$ factors of Mycobacterium tuberculosis. FEMS Microbiol Rev 2006; 30: 926-41

[40] Manganelli R, Voskuil MI, Schoolnik GK, Smith I. The Mycobacterium tuberculosis ECF sigma factor $\sigma^{\mathrm{E}}$ : role in global gene expression and survival in macrophages. Mol Microbiol 2001; 41: 423-37.

[41] Kwak J, Dharmatilake AJ, Jiang H, Kendrick KE. Differential regulation of fts $Z$ transcription during septation of Streptomyces griseus. J Bacteriol 2001; 183: 5092-101.

[42] Garrido T, Sanchez M, Palacios P, Aldea M, Vicente M. Transcription of fts $Z$ oscillates during the cell cycle of Escherichia coli. EMBO J 1993; 12: 3957-65.

[43] Aldea M, Garrido T, Pla J, Vicente $M$. Division genes in Escherichia coli are expressed coordinately to cell septum requirements by gearbox promoters. EMBO J 1990; 9: 3787-94.

[44] Desjardin LE, Hayes LG, Sohaskey CD, Wayne LG, Eisenach KD. Microaerophilic induction of the alpha-crystallin chaperone protein homologue (hspX) mRNA of Mycobacterium tuberculosis. J Bacteriol 2001; 183: 5311-6.

[45] Sherman DR, Voskuil M, Schnappinger D, Liao R, Harrell MI, Schoolnik GK. Regulation of the Mycobacterium tuberculosis hypoxic response gene encoding alpha-crystallin. Proc Natl Acad Sci USA 2001; 98: 7534-9.

[46] Hampshire T, Soneji S, Bacon J, et al. Stationary phase gene expression of Mycobacterium tuberculosis following a progressive nutrient depletion: a model for persistent organisms? Tuberculosis (Edinb) 2004; 84: 228-38.

[47] Voskuil MI, Visconti KC, Schoolnik GK. Mycobacterium tuberculosis gene expression during adaptation to stationary phase and low-oxygen dormancy. Tuberculosis (Edinb) 2004; 84: 218-27.

[48] Gordillo S, Guirado E, Gil O, et al. Usefulness of acr expression for monitoring latent Mycobacterium tuberculosis bacilli in 'In Vitro' and 'In Vivo' experimental models. Scand J Immunol 2006; 64: 30-9 